\title{
Are Functional Foods Marketed in Honduras a Healthy Option?
}

\author{
Adriana Hernández Santana* (D), Sofía Raquel Mejía Motiño, Adriana B. Di Iorio \\ Food Science and Technology Department, Zamorano University, San Antonio de Oriente, Honduras \\ Email: *ahernandez@zamorano.edu
}

How to cite this paper: Santana, A.H., Motiño, S.R.M. and Di Iorio, A.B. (2019) Are Functional Foods Marketed in Honduras a Healthy Option? Food and Nutrition Sciences, 10, 719-734. https://doi.org/10.4236/fns.2019.107053

Received: May 20, 2019

Accepted: July 6, 2019

Published: July 9, 2019

Copyright (c) 2019 by author(s) and Scientific Research Publishing Inc. This work is licensed under the Creative Commons Attribution International License (CC BY 4.0).

http://creativecommons.org/licenses/by/4.0/ (c) (i) Open Access

\begin{abstract}
Background: Functional foods have been proposed as vehicles to prevent diseases in response to disease increase throughout the world. Methods: Descriptive cross-sectional study. The nutritional labeling of processed functional foods (PFF) commercially available in Honduras was examined to consider health benefits based on functionality according to the Central American Technical Regulation (CATR) and critical nutrient content according to the profile of the Panamerican Health Organization (PAHO). Results: Out of a national sample of 631 commercial processed foods (CPF), 144 were defined as functional; sweetened and flavored yogurts and cereal bars reached the highest proportions (70\% and 66\%) of products available in their respective categories. None of the categories was on average "low in calories" according to criteria of CATR; sweetened breakfast cereals were the most caloric $(180 \mathrm{kcal})$ and only sweetened juices had "calorie free" products (15\%). Prepared meat did not meet the criterion of "low cholesterol" even though all the products in this category were the reduced fat version of the original CPF. All categories of cereal-based products met the "source of dietary fiber" criteria and $64 \%$ of baked products were "high in dietary fiber". More than $70 \%$ of PFF exceeded the sugar recommendation of the PAHO profile, mainly sweetened breakfast cereals (100\%) and sweetened juices (93\%). $49 \%$ of the products exceeded the sodium recommendation, particularly baked products $(100 \%)$ and cheeses (86\%); $100 \%$ of the later exceeded the recommendation of total fats. More than $60 \%$ of products simultaneously exceeded between 2 and 3 of PAHO profile criteria; $5 \%$ exceeded all the criteria and $4 \%$ met all the PAHO profile criteria. The average price of PFF was $\$ 2.34$, while that of conventional products was $\$ 1.87$; sweetened breakfast cereals were the most expensive (\$3.49 and \$3.28) and sweetened juices were the cheapest (\$1.79 and \$1.89) for both CPF and PFF. Conclusions: PFF marketed in Honduras have an excessive content of critical nutrients. These results demonstrate the need for a rigorous and mandatory regulation in the production, advertising
\end{abstract}


and sale of functional and conventional processed foods.

\section{Keywords}

Functional Foods, Sugars, Sodium, Fast Foods, Cholesterol

\section{Introduction}

To date there is a high availability of dense foods in energy, fat, sugar and salt at low cost, which, accompanied by a sedentary lifestyle, have contributed to an increase in the prevalence of obesity and chronic diseases throughout the world. The treatment of these diseases is extremely costly and represents a significant economic and social burden for countries [1]-[5].

For this reason, it has been necessary to identify strategies to reduce the consumption of these critical nutrients, preventing diseases through food. Hence, the food industry has proposed "functional foods" as a vehicle to improve the health of the communities [1] [3].

Thus, in recent years, the science of nutrition has undergone significant changes due to growing evidence of the effectiveness of dietary components and bioactive compounds present in foods with specific physiological functions through the adoption of healthy eating patterns [1] [2] [3] [6] [7] [8] [9].

The wide media coverage of this phenomenon has led to consumers being increasingly aware of their health, recognizing the direct influence of food in the prevention of diseases. As a result, there is a greater demand for food products that meet a balanced content of macronutrients and also provide additional health benefits [1] [2] [3] [7] [9].

The concept of functional food was developed initially in Japan as a means for the prevention of chronic diseases linked to old age in that country, whose life expectancy is increasingly high. Japan is also the only country with legislation for functional food denominated Food with Specified Health Uses (FOSHU) [1] [5] [8] [10].

Worldwide, there is no standardized definition of functional foods. Different organizations and health institutions such as the International Food Information Council (IFIC), Codex Alimentarius and the Expert Panel Report of the Institute of Food Technology (IFT) differ very little in their definitions, expressing the basic idea that food is functional when in addition to meeting nutritional needs, it offers other beneficial health properties [3] [11] [12].

These can be natural or processed, either because a certain substance has been removed to produce a health benefit, such as reducing sugar and sodium, or due to adding a food component that has scientific evidence of producing a beneficial effect on health when consumed in normal amounts within the regular diet [1] [11]. This represents a challenge to the food industry since the consumer also demands certain sensory and organoleptic attributes, such as sweet and salty 
flavors [2].

There is no international regulation to monitor the composition of functional foods, as a result, their preparation is subject only to recommendations that vary from one country to another [10]. The main objective of this study will be to characterize commercially available functional foods in Honduras and evaluate their critical nutrient content according to the criteria of the Central American Technical Regulation (CATR) [13], and the Nutrient Profile Model of the Pan American Health Organization (PAHO) [14] in order to consider their health benefits, both by functionality and critical nutrient content.

\section{Materials and Methods}

The study has a descriptive cross-sectional design based on the review of nutritional labeling in commercially processed and ultra-processed foods (hereinafter referred to as processed commercial foods) available in Honduras, distinguishing those that could be considered as functional. Descriptive statistics measures were used such as the mean, standard deviation, standard error, coefficient of variation and minimum value, maximum value and range for the analysis of the information. The results are presented in the frequency distribution tables.

The study was developed in the Human Nutrition Laboratory of Zamorano Panamerican Agricultural School from April 2018 to May 2019.

Convenience sampling was carried out according to the inclusion and exclusion criteria. The sample was composed of processed commercial foods (PCF), and functional processed functional foods (FFP), that were acquired by trained personnel in international supermarket chains with a greater national presence. The personnel exhaustively reviewed the different shelves with available PFF. The packaging and nutritional labeling of each product was photographed to create a photographic database. No electronic product searches were conducted to ensure its availability in the Honduran market.

The inclusion criteria for the selection of the products included the following: processed or ultra-processed foods offered to audiences over three years of age; that the list of ingredients indicating the presence of at least one functional ingredient and/or the declaration of modifications to the nutrient content and food additives; that had nutritional labeling and place of origin. The exclusion criterion for the selection of the products included the following: processed or ultra-processed foods offered to audiences under three years of age and repeated products.

To characterize the FFP, the caloric, cholesterol and fiber content was evaluated according to the CATR.

\subsection{Central American Technical Regulation}

CATR on its 67.01.60:10 version, establishes the guidelines to prepare the nutritional labeling of pre-packaged food products for human consumption for the population from 3 years of age [13]. The parameters described below were used 
to evaluate the content of calories, cholesterol and fiber in the sampled products:

1) Calories: foods "low" in calories are those that do not contain more than 40 kcal per serving of product. "Calorie free" foods are those that contain no more than $5 \mathrm{kcal}$ per serving of product.

2) Cholesterol: foods "low in cholesterol" are those that contain no more than $20 \mathrm{mg}$ per serving of product. "Cholesterol free" foods are those that contain no more than $2 \mathrm{mg}$ per serving of product.

3) Fiber: foods "source of dietary fiber" are those that contain a minimum of 3 g per $100 \mathrm{~g}$ of product. Foods "high in dietary fiber" are those that contain a minimum of $6 \mathrm{~g}$ per $100 \mathrm{~g}$ of product. Grams of dietary fiber per $100 \mathrm{~g}$ of product were calculated for this parameter.

The CATR also provides criteria for classifying foods as "reduced in calories" and "reduced in cholesterol", however, due to information limitations at the time of the study, these criteria were not used.

The products were grouped into nine categories dictated by the PAHO nutrient profile model [14], (cheeses, cookies, sweetened juices, sweetened breakfast cereals, cereal bars, prepared meats, baked products, sweetened and flavored yogurts and seasonings). The characterization was carried out according to the study by Sunkara and Verghese [3], grouping these categories according to their basic ingredient in the following groups: functional dairy products, functional carbohydrate-based products, functional beverages, functional fat based products and functional protein-based products.

The PAHO nutrient profile was used to identify the number of products that comply with the recommendations on critical nutrient content (sodium, sweeteners, sugar, fats).

\subsection{PAHO Nutrient Profile Model}

The nutrient profile model is a tool for identifying foods and beverages that contain excessive amounts of free sugars, salt, total fats, saturated fats and trans fatty acids [14]. Excessive amounts of critical nutrients analyzed in this study were identified with the following criteria:

1) Sodium: if the ratio between the amount of sodium $(\mathrm{mg})$ in any given quantity of the product and the energy (kcal) is equal to or greater than 1:1.

2) Free sugars: if in any given quantity of the product the amount of energy (kcal) coming from the free sugars (grams of free sugars $\times 4 \mathrm{kcal}$ ) is equal to or greater than $10 \%$ of the total energy (kcal).

3) Total fats: if in any given quantity of the product the amount of energy (kcal) from the total fats (grams of total fats $\times 9 \mathrm{kcal}$ ) is equal to or greater than $30 \%$ of the total energy ( $\mathrm{kcal})$.

4) Saturated fats: if in any given quantity of the product the amount of energy (kcal) from saturated fats (grams of saturated fats $\times 9 \mathrm{kcal}$ ) is equal to or greater than $10 \%$ of the total energy (kcal).

5) Contains other sweeteners: if the list of ingredients includes artificial or non-caloric natural sweeteners or caloric sweeteners (polyalcohols). 
Based on this information, a database was created in Excel (Microsoft, Redmond, WA, USA) with 20 variables: product name, country of origin, manufacturing company, list of ingredients, portion size, number of servings, calories, total fat $(\mathrm{g})$, percentage of total fat, saturated fat $(\mathrm{g})$, percentage of saturated fat, cholesterol (mg), sodium $(\mathrm{mg})$, ratio of sodium: calories, protein $(\mathrm{g})$, total carbohydrates (g), free sugars $(\mathrm{g})$, percentage of sugar, dietary fiber $(\mathrm{g})$, fiber in 100 $\mathrm{g}$, presence of sweeteners and price.

In addition, an evaluation was made of products containing sugar or other sweeteners and sodium within the first five positions in the list of ingredients. Price per product and price differences between CPF and PFF were analyzed by product category.

\section{Results}

631 processed food products were evaluated, of which 144 were defined as functional, representing $23 \%$ of the available processed foods. The categories with the greatest presence of functional products were sweetened and flavored yogurts (70\%), and cereal bars $(66 \%)$, while the categories with less presence of functional products were prepared meats (6\%) and cheeses (7\%). Table 1 presents the number of foods per category that were included in the study. Products were identified from ten countries and 49 companies, mostly from the United States (47\%). This is due to the extensive commercial relationship that the United States maintains with Honduras as a result of free trade agreements that facilitate the flow of products and goods between countries [15] [16]. 21\% of products were of Costa Rican origin and 13\% of Mexican origin; 16\% were of Central American origin and 2\% of these of Honduran origin.

PFF categories were further characterized according to Sunkara and Verghese's study [3], based on the products base ingredient. Table 2 presents how

Table 1. A number of functional food products included in the study and percentage that they represent compared to conventionally processed products by category of the PAHO nutrient profile.

\begin{tabular}{cccc}
\hline Food Category & Total Available & Total Functional & PFF Percentage \\
\hline Sweetened and flavored yogurts & 33 & 23 & $70 \%$ \\
Cereal bars & 32 & 21 & $66 \%$ \\
Sweetened juices & 64 & 27 & $42 \%$ \\
Sweetened breakfast cereals & 64 & 25 & $39 \%$ \\
Baked products & 82 & 14 & $17 \%$ \\
Cookies & 135 & 17 & $13 \%$ \\
Seasonings & 46 & 5 & $11 \%$ \\
Cheeses & 94 & 7 & $7 \%$ \\
Prepared meat & 81 & 5 & $6 \%$ \\
Total & 631 & 144 & $23 \%$ \\
\hline
\end{tabular}


Table 2. Categorization of products according to Sunkara and Verghese [3].

\begin{tabular}{|c|c|c|}
\hline Categorization (Sunkara and Verghese) & $\mathrm{N}$ & Sample Percentage \\
\hline Functional dairy products & 30 & \multirow{3}{*}{$21 \%$} \\
\hline Cheeses & 7 & \\
\hline Sweetened and flavored yogurts & 23 & \\
\hline Functional carbohydrate-based products & 77 & \multirow{5}{*}{$53 \%$} \\
\hline Baked products & 14 & \\
\hline Cereal bars & 21 & \\
\hline Sweetened breakfast cereals & 25 & \\
\hline Cookies & 17 & \\
\hline Functional beverages & 27 & \multirow[b]{2}{*}{$19 \%$} \\
\hline Sweetened juices & 27 & \\
\hline Functional fat based products & 5 & \multirow{2}{*}{$3 \%$} \\
\hline Seasonings & 5 & \\
\hline Functional protein-based products & 5 & \multirow[b]{2}{*}{$3 \%$} \\
\hline Prepared meats & 5 & \\
\hline Total & 144 & $100 \%$ \\
\hline
\end{tabular}

PAHO categories where characterized, the number of products each group and what percentage of the sample each group represents. Functional carbohydrate-based products were the largest group, composed of four PAHO categories and representing $53 \%$ of the total sample, followed by functional dairy products composed of two PAHO categories and representing $21 \%$ of the total sample.

The CATR indicates that the "low calorie" products are those that contribute less than $40 \mathrm{kcal}$ per serving of product; however, no category met this criterion when its average calorie content was calculated. The sweetened breakfast cereals, as can be seen in Table 3, present the highest caloric intake with an average per product portion of $180 \mathrm{kcal}$, followed by cookies ( $130 \mathrm{kcal})$ and sweetened and flavored yogurts $(124 \mathrm{kcal})$, with maximum values of 378 $\mathrm{kcal}, 170 \mathrm{kcal}$ and $198 \mathrm{kcal}$, respectively. Sweetened breakfast cereals also have the lowest average regarding fiber content $(3 \mathrm{~g})$.

$100 \%$ of products in the categories of sweetened juices, baked products and sweetened breakfast cereals met the "cholesterol free" criteria. Likewise, the categories of cereal bars (86\%), cheeses $(71 \%)$, and cookies $(71 \%)$ presented a high percentage of products that met this criterion. None of the products in the prepared meats category were "cholesterol free".

Only $15 \%$ of products in the category of sweetened juices met the "calorie free" criterion. The category with the highest percentage of products that met the criterion of "high in dietary fiber" was that of baked products (64\%), followed by cereal bars (43\%), cookies (29\%) and sweetened breakfast cereals (8\%). 
Table 3. Mean, standard deviation, standard error, coefficient of variation, minimum maximum and range value of caloric content, cholesterol and fiber per product portion of each category of processed foods, pursuant to criteria of the CATR.

\begin{tabular}{|c|c|c|c|c|c|c|c|c|c|}
\hline Criteria CATR & Food Category & $\mathbf{N}$ & Avg. & SD & SE & $\mathrm{CV}$ & Min & $\operatorname{Max}$ & Range \\
\hline \multirow{9}{*}{$\begin{array}{l}\text { Low in calories } \\
(\leq 40 \mathrm{kcal})\end{array}$} & Sweetened juices & 27 & $84 \mathrm{kcal}$ & $49 \mathrm{kcal}$ & $9 \mathrm{kcal}$ & $0.6 \mathrm{kcal}$ & $5 \mathrm{kcal}$ & $160 \mathrm{kcal}$ & $155 \mathrm{kcal}$ \\
\hline & Seasonings & 5 & $43 \mathrm{kcal}$ & $21 \mathrm{kcal}$ & $9 \mathrm{kcal}$ & $0.5 \mathrm{kcal}$ & $10 \mathrm{kcal}$ & $75 \mathrm{kcal}$ & $65 \mathrm{kcal}$ \\
\hline & Baked products & 14 & $71 \mathrm{kcal}$ & $15 \mathrm{kcal}$ & $4 \mathrm{kcal}$ & $0.2 \mathrm{kcal}$ & $50 \mathrm{kcal}$ & $101 \mathrm{kcal}$ & $51 \mathrm{kcal}$ \\
\hline & Cheeses & 7 & $59 \mathrm{kcal}$ & $24 \mathrm{kcal}$ & $9 \mathrm{kcal}$ & $0.4 \mathrm{kcal}$ & $25 \mathrm{kcal}$ & $98 \mathrm{kcal}$ & $73 \mathrm{kcal}$ \\
\hline & Sweetened and flavored yogurts & 23 & $124 \mathrm{kcal}$ & $46 \mathrm{kcal}$ & $10 \mathrm{kcal}$ & $0.4 \mathrm{kcal}$ & $50 \mathrm{kcal}$ & $198 \mathrm{kcal}$ & $148 \mathrm{kcal}$ \\
\hline & Cereal bars & 21 & $117 \mathrm{kcal}$ & $33 \mathrm{kcal}$ & $7 \mathrm{kcal}$ & $0.3 \mathrm{kcal}$ & $70 \mathrm{kcal}$ & $180 \mathrm{kcal}$ & $110 \mathrm{kcal}$ \\
\hline & Prepared meat & 5 & $67 \mathrm{kcal}$ & $17 \mathrm{kcal}$ & $8 \mathrm{kcal}$ & $0.3 \mathrm{kcal}$ & $35 \mathrm{kcal}$ & $82 \mathrm{kcal}$ & $47 \mathrm{kcal}$ \\
\hline & Sweetened breakfast cereals & 25 & $180 \mathrm{kcal}$ & $97 \mathrm{kcal}$ & $19 \mathrm{kcal}$ & $0.5 \mathrm{kcal}$ & $90 \mathrm{kcal}$ & $378 \mathrm{kcal}$ & $288 \mathrm{kcal}$ \\
\hline & Cookies & 17 & $130 \mathrm{kcal}$ & $26 \mathrm{kcal}$ & $6 \mathrm{kcal}$ & $0.2 \mathrm{kcal}$ & $85 \mathrm{kcal}$ & $170 \mathrm{kcal}$ & $85 \mathrm{kcal}$ \\
\hline \multirow{7}{*}{$\begin{array}{l}\text { Low cholesterol } \\
(\leq 20 \mathrm{mg})\end{array}$} & Seasonings & 5 & $2 \mathrm{mg}$ & $2 \mathrm{mg}$ & $1 \mathrm{mg}$ & $1.2 \mathrm{mg}$ & $0 \mathrm{mg}$ & $5 \mathrm{mg}$ & $5 \mathrm{mg}$ \\
\hline & Baked products & 14 & $0 \mathrm{mg}$ & $1 \mathrm{mg}$ & $0 \mathrm{mg}$ & $1.5 \mathrm{mg}$ & $0 \mathrm{mg}$ & $3 \mathrm{mg}$ & $3 \mathrm{mg}$ \\
\hline & Cheeses & 7 & $6 \mathrm{mg}$ & $9 \mathrm{mg}$ & $3 \mathrm{mg}$ & $1.5 \mathrm{mg}$ & $0 \mathrm{mg}$ & $21 \mathrm{mg}$ & $21 \mathrm{mg}$ \\
\hline & Sweetened and flavored yogurts & 23 & $5 \mathrm{mg}$ & $6 \mathrm{mg}$ & $1 \mathrm{mg}$ & $1.1 \mathrm{mg}$ & $0 \mathrm{mg}$ & $20 \mathrm{mg}$ & $20 \mathrm{mg}$ \\
\hline & Cereal bars & 21 & $4 \mathrm{mg}$ & $9 \mathrm{mg}$ & $2 \mathrm{mg}$ & $2.7 \mathrm{mg}$ & $0 \mathrm{mg}$ & $37 \mathrm{mg}$ & $37 \mathrm{mg}$ \\
\hline & Prepared meat & 5 & $116 \mathrm{mg}$ & $192 \mathrm{mg}$ & $86 \mathrm{mg}$ & $1.7 \mathrm{mg}$ & $15 \mathrm{mg}$ & $500 \mathrm{mg}$ & $485 \mathrm{mg}$ \\
\hline & Cookies & 17 & $1.5 \mathrm{mg}$ & $2 \mathrm{mg}$ & $1 \mathrm{mg}$ & $1.5 \mathrm{mg}$ & $0 \mathrm{mg}$ & $5 \mathrm{mg}$ & $5 \mathrm{mg}$ \\
\hline \multirow{4}{*}{$\begin{array}{l}\text { Source of dietary fiber } \\
(\geq 3 \mathrm{~g})\end{array}$} & Baked products & 14 & $7 \mathrm{~g}$ & $2 \mathrm{~g}$ & $1 \mathrm{~g}$ & $0.3 \mathrm{~g}$ & $3 \mathrm{~g}$ & $10 \mathrm{~g}$ & $7 \mathrm{~g}$ \\
\hline & Cereal bars & 21 & $6 \mathrm{~g}$ & $4 \mathrm{~g}$ & $1 \mathrm{~g}$ & $0.6 \mathrm{~g}$ & $2 \mathrm{~g}$ & $17 \mathrm{~g}$ & $15 \mathrm{~g}$ \\
\hline & Sweetened breakfast cereals & 25 & $3 \mathrm{~g}$ & $2 \mathrm{~g}$ & $0 \mathrm{~g}$ & $0.6 \mathrm{~g}$ & $0 \mathrm{~g}$ & $10 \mathrm{~g}$ & $10 \mathrm{~g}$ \\
\hline & Cookies & 17 & $4 \mathrm{~g}$ & $3 g$ & $1 \mathrm{~g}$ & $0.8 \mathrm{~g}$ & $0 \mathrm{~g}$ & $10 \mathrm{~g}$ & $10 \mathrm{~g}$ \\
\hline
\end{tabular}

aper standardized portion of $100 \mathrm{~g}$ of product.

Prepared meats presented the highest cholesterol content with an average of $116 \mathrm{mg}$ per serving of product and a maximum value of $500 \mathrm{mg}$, followed by cheeses and sweetened and flavored yogurts with maximum values of $21 \mathrm{mg}$ and $20 \mathrm{mg}$ respectively.

Table 4 presents food by category and the percentage that exceeded each of the criteria of the PAHO nutrient profile mode ${ }^{14}$.

$100 \%$ of products in the category of cheeses exceeded the amount of total fats, $71 \%$ exceeded the limit of saturated fats and $86 \%$ exceeded the limit of sodium. $80 \%$ of products in the categories of seasonings and prepared meats exceeded the limit of total fats, saturated fats and sodium. 59\% of cookies exceeded both the total fat content and the saturated fat content.

$100 \%$ of baked products exceeded the recommended sodium limit, while $100 \%$ of sweetened breakfast cereals exceeded the recommended sugar content and more than $70 \%$ also exceeded the recommendation for sodium. The category of sweetened juices presented an excess of sugar in $93 \%$ of products and $22 \%$ also contained other sweeteners. More than $60 \%$ of cookies surpassed the sugar 
Table 4. Number and percentage of products that exceed the criteria of the PAHO Nutrient Profile Model.

\begin{tabular}{|c|c|c|c|c|c|}
\hline Food Category & Total Fats & Saturated fat & Sodium & Sugar & Sweeteners \\
\hline Sweetened juices $(\mathrm{n}=27)$ & $8(30 \%)$ & $1(4 \%)$ & $13(48 \%)$ & $25(93 \%)$ & $6(22 \%)$ \\
\hline Seasonings $(\mathrm{n}=5)$ & $4(80 \%)$ & $4(80 \%)$ & $4(80 \%)$ & $1(20 \%)$ & $0(0 \%)$ \\
\hline Baked products $(\mathrm{n}=14)$ & $1(7 \%)$ & $2(14 \%)$ & $14(100 \%)$ & $4(29 \%)$ & $0(0 \%)$ \\
\hline Cheeses $(n=7)$ & $7(100 \%)$ & $5(71 \%)$ & $6(86 \%)$ & $3(43 \%)$ & $0(0 \%)$ \\
\hline $\begin{array}{l}\text { Sweetened and flavored yogurts } \\
\qquad(\mathrm{n}=23)\end{array}$ & $3(13)$ & $10(43 \%)$ & $4(17 \%)$ & $15(65 \%)$ & $6(26 \%)$ \\
\hline Cereal bars $(n=21)$ & $9(43 \%)$ & $8(38 \%)$ & $3(14 \%)$ & $18(86 \%)$ & $2(9 \%)$ \\
\hline Prepared meat $(\mathrm{n}=5)$ & $4(80 \%)$ & $4(80 \%)$ & $4(80 \%)$ & $2(40 \%)$ & $0(0 \%)$ \\
\hline Sweetened breakfast cereals $(\mathrm{n}=25)$ & $0(0 \%)$ & $1(4 \%)$ & $18(72 \%)$ & $25(100 \%)$ & $0(0 \%)$ \\
\hline Cookies $(\mathrm{n}=17)$ & $10(59 \%)$ & $10(59 \%)$ & $4(24 \%)$ & $11(65 \%)$ & $1(6 \%)$ \\
\hline Total sample $(\mathrm{n}=144)$ & $46(32 \%)$ & $36(25 \%)$ & $70(49 \%)$ & $104(72 \%)$ & $15(10 \%)$ \\
\hline
\end{tabular}

limit and 6\% also showed the presence of other sweeteners such as sucralose and acesulfame K.

In Table 5 it can be observed that seasonings presented the highest average of calories derived from fat (73\%) with a maximum value of $100 \%$, followed by cheeses whose average total fat content was $53 \%$. Cheeses presented the highest average saturated fats of the whole sample (29\%). Prepared meats presented 51\% of calories derived from fat and a maximum value of $64 \%$. Sweetened juices presented a maximum value of $75 \%$ regarding total fat content. The average of saturated fats, both in seasonings (12\%) and in prepared meats (11\%), exceeds the recommended levels.

Prepared meats have the highest sodium ratio $(5.2 \mathrm{mg} / \mathrm{kcal})$ with a maximum value of $8.1 \mathrm{mg} / \mathrm{kcal}$, followed by seasonings with an average of $3.6 \mathrm{mg} / \mathrm{kcal}$ and a maximum value of $12 \mathrm{mg} / \mathrm{kcal}$. Cheeses $(2.4 \mathrm{mg} / \mathrm{kcal})$ and baked products $(2$ $\mathrm{mg} / \mathrm{kcal}$ ) also presented high means for sodium content with maximum values of $7.2 \mathrm{mg} / \mathrm{kcal}$ and $2.8 \mathrm{mg} / \mathrm{kcal}$, respectively.

Sweetened juices presented the highest average for caloric content derived from sugar (72\%) with a maximum value of $100 \%$, followed by sweetened and flavored yogurts with an average of $35 \%$ and a maximum value of $69 \%$. Sweetened breakfast cereals presented an average of $28 \%$ and a maximum value of $42 \%$. Cereal bars had a maximum value of $58 \%$.

Table 6 shows that six products of the whole sample (4\%), meet all the criteria of the nutrient profile and half of them are in the cookie category. $30 \%$ of products in the complete sample exceed one of the criteria, mainly in the categories of baked products (57\%) and sweetened juices (44\%). 53\% of the total sample exceeds two criteria of the nutrient profile, mainly sweetened breakfast cereals (68\%). $24 \%$ of products in the sample exceed 3 criteria of the nutrient profile, where $71 \%$ 
A. H. Santana et al.

Table 5. Mean, standard deviation, standard error, coefficient of variation, minimum, maximum and range value of critical nutrient content per product portion of each food category processed according to the PAHO profile.

\begin{tabular}{|c|c|c|c|c|c|c|c|c|c|}
\hline Critical Nutrient & Food Category & $\mathbf{N}$ & Avg. & SD & SE & $\mathrm{CV}$ & Min & $\operatorname{Max}$ & Range \\
\hline \multirow[t]{9}{*}{ Total fat $(<30 \%)$} & Sweetened juices & 27 & $13 \%$ & $20 \%$ & $3.8 \%$ & $1.5 \%$ & $0 \%$ & $75 \%$ & $75 \%$ \\
\hline & Seasonings & 5 & $73 \%$ & $37 \%$ & $16.5 \%$ & $0.5 \%$ & $0 \%$ & $100 \%$ & $100 \%$ \\
\hline & Baked products & 14 & $14 \%$ & $6 \%$ & $1.6 \%$ & $0.4 \%$ & $7 \%$ & $33 \%$ & $26 \%$ \\
\hline & Cheeses & 7 & $58 \%$ & $23 \%$ & $8.7 \%$ & $0.4 \%$ & $17 \%$ & $88 \%$ & $71 \%$ \\
\hline & Sweetened and flavored yogurts & 23 & $15 \%$ & $11 \%$ & $2.3 \%$ & $0.7 \%$ & $0 \%$ & $38 \%$ & $38 \%$ \\
\hline & Cereal bars & 21 & $28 \%$ & $12 \%$ & $2.6 \%$ & $0.4 \%$ & $15 \%$ & $60 \%$ & $45 \%$ \\
\hline & Prepared meat & 5 & $51 \%$ & $17 \%$ & $7.6 \%$ & $0.3 \%$ & $19 \%$ & $64 \%$ & $45 \%$ \\
\hline & Sweetened breakfast cereals & 25 & $9 \%$ & $4 \%$ & $0.8 \%$ & $0.4 \%$ & $0 \%$ & $17 \%$ & $17 \%$ \\
\hline & Cookies & 17 & $29 \%$ & $10 \%$ & $2.4 \%$ & $0.3 \%$ & $11 \%$ & $41 \%$ & $30 \%$ \\
\hline \multirow[t]{9}{*}{ Saturated fat $(<10 \%)$} & Sweetened juices & 27 & $2 \%$ & $5 \%$ & $1.0 \%$ & $2.5 \%$ & $0 \%$ & $27 \%$ & $27 \%$ \\
\hline & Seasonings & 5 & $12 \%$ & $7 \%$ & $3.1 \%$ & $0.6 \%$ & $0 \%$ & $20 \%$ & $20 \%$ \\
\hline & Baked products & 14 & $6 \%$ & $4 \%$ & $1.1 \%$ & $0.7 \%$ & $0 \%$ & $17 \%$ & $17 \%$ \\
\hline & Cheeses & 7 & $29 \%$ & $21 \%$ & $7.9 \%$ & $0.7 \%$ & $0 \%$ & $64 \%$ & $64 \%$ \\
\hline & Sweetened and flavored yogurts & 23 & $9 \%$ & $7 \%$ & $1.5 \%$ & $0.8 \%$ & $0 \%$ & $24 \%$ & $24 \%$ \\
\hline & Cereal bars & 21 & $9 \%$ & $6 \%$ & $1.3 \%$ & $0.7 \%$ & $0 \%$ & $19 \%$ & $19 \%$ \\
\hline & Prepared meat & 5 & $11 \%$ & $6 \%$ & $2.7 \%$ & $0.5 \%$ & $0 \%$ & $19 \%$ & $19 \%$ \\
\hline & Sweetened breakfast cereals & 25 & $2 \%$ & $3 \%$ & $0.6 \%$ & $1.5 \%$ & $0 \%$ & $15 \%$ & $15 \%$ \\
\hline & Cookies & 17 & $8 \%$ & $6 \%$ & $1.5 \%$ & $0.8 \%$ & $0 \%$ & $17 \%$ & $17 \%$ \\
\hline \multirow[t]{9}{*}{ Sodium (1 mg:1 kcal) } & Sweetened juices & 27 & 1.4 & 1.5 & 0.3 & 1.0 & 0.0 & 5.7 & 5.6 \\
\hline & Seasonings & 5 & 3.6 & 4.4 & 1.9 & 1.2 & 0.0 & 12.0 & 12.0 \\
\hline & Baked products & 14 & 2.0 & 0.3 & 0.1 & 0.2 & 1.5 & 2.8 & 1.3 \\
\hline & Cheeses & 7 & 2.4 & 2.0 & 0.8 & 0.8 & 0.8 & 7.2 & 6.4 \\
\hline & Sweetened and flavored yogurts & 23 & 0.7 & 0.3 & 0.1 & 0.4 & 0.4 & 1.3 & 0.9 \\
\hline & Cereal bars & 21 & 0.7 & 0.3 & 0.1 & 0.4 & 0.1 & 1.2 & 1.0 \\
\hline & Prepared meat & 5 & 5.2 & 2.7 & 1.2 & 0.5 & 0.1 & 8.1 & 8.0 \\
\hline & Sweetened breakfast cereals & 25 & 1.3 & 0.4 & 0.1 & 0.3 & 0.5 & 2.3 & 1.9 \\
\hline & Cookies & 17 & 0.9 & 0.6 & 0.1 & 0.6 & 0.0 & 2.2 & 2.2 \\
\hline \multirow[t]{9}{*}{ Sugar $(<10 \%)$} & Sweetened juices & 27 & $72 \%$ & $34 \%$ & $6.5 \%$ & $0.5 \%$ & $0 \%$ & $100 \%$ & $100 \%$ \\
\hline & Seasonings & 5 & $10 \%$ & $15 \%$ & $6.7 \%$ & $1.5 \%$ & $0 \%$ & $40 \%$ & $40 \%$ \\
\hline & Baked products & 14 & $8 \%$ & $4 \%$ & $1.1 \%$ & $0.5 \%$ & $0 \%$ & $14 \%$ & $14 \%$ \\
\hline & Cheeses & 7 & $6 \%$ & $7 \%$ & $2.6 \%$ & $1.2 \%$ & $0 \%$ & $16 \%$ & $16 \%$ \\
\hline & Sweetened and flavored yogurts & 23 & $35 \%$ & $24 \%$ & $5.0 \%$ & $0.7 \%$ & $0 \%$ & $69 \%$ & $69 \%$ \\
\hline & Cereal bars & 21 & $25 \%$ & $14 \%$ & $3.1 \%$ & $0.6 \%$ & $0 \%$ & $58 \%$ & $58 \%$ \\
\hline & Prepared meat & 5 & $4 \%$ & $5 \%$ & $2.2 \%$ & $1.3 \%$ & $0 \%$ & $10 \%$ & $10 \%$ \\
\hline & Sweetened breakfast cereals & 25 & $28 \%$ & $8 \%$ & $1.6 \%$ & $0.3 \%$ & $12 \%$ & $42 \%$ & $30 \%$ \\
\hline & Cookies & 17 & $16 \%$ & $9 \%$ & $2.2 \%$ & $0.6 \%$ & $0 \%$ & $28 \%$ & $28 \%$ \\
\hline
\end{tabular}


Table 6. Number and percentage of products by category that exceed one or more criteria of the PAHO Nutrient Profile Model.

\begin{tabular}{cccccc}
\hline Food Category & $\begin{array}{c}\text { Meet all } \\
\text { criteria }\end{array}$ & $\begin{array}{c}\text { Exceed 1 } \\
\text { criterion }\end{array}$ & $\begin{array}{c}\text { Exceed 2 } \\
\text { criterion }\end{array}$ & $\begin{array}{c}\text { Exceed 3 } \\
\text { criterion }\end{array}$ & $\begin{array}{c}\text { Exceed 4 } \\
\text { or more } \\
\text { criteria }\end{array}$ \\
\hline $\begin{array}{c}\text { Sweetened juices }(\mathrm{n}=27) \\
\text { Seasonings }(\mathrm{n}=5)\end{array}$ & $0(0 \%)$ & $12(44 \%)$ & $4(15 \%)$ & $11(41 \%)$ & $0(0 \%)$ \\
Baked products $(\mathrm{n}=14)$ & $0(0 \%)$ & $0(0 \%)$ & $2(40 \%)$ & $3(60 \%)$ & $0(0 \%)$ \\
Cheeses $(\mathrm{n}=7)$ & $0(0 \%)$ & $0(0 \%)$ & $1(14 \%)$ & $5(71 \%)$ & $1(14 \%)$ \\
Sweetened and flavored yogurts $(\mathrm{n}=23)$ & $2(9 \%)$ & $7(30 \%)$ & $11(48 \%)$ & $3(13 \%)$ & $0(0 \%)$ \\
Cereal bars $(\mathrm{n}=21)$ & $0(0 \%)$ & $8(38 \%)$ & $8(38 \%)$ & $2(10 \%)$ & $3(14 \%)$ \\
Prepared meat $(\mathrm{n}=5)$ & $1(20 \%)$ & $0(0 \%)$ & $0(0 \%)$ & $2(40 \%)$ & $2(40 \%)$ \\
Sweetened breakfast cereals $(\mathrm{n}=25)$ & $0(0 \%)$ & $7(28 \%)$ & $17(68 \%)$ & $1(4 \%)$ & $0(0 \%)$ \\
Cookies $(\mathrm{n}=17)$ & $3(18 \%)$ & $1(6 \%)$ & $5(29 \%)$ & $7(41 \%)$ & $1(6 \%)$ \\
Total sample $(\mathrm{n}=144)$ & $6(4 \%)$ & $43(30 \%)$ & $53(37 \%)$ & $35(24 \%)$ & $7(5 \%)$ \\
\hline
\end{tabular}

of cheeses have this characteristic. $5 \%$ of products in the whole sample exceed four or all of the criteria of the nutrient profile, mainly prepared meats (40\%) and cereal bars (14\%).

Although one of the most sweetened categories was sweetened juices, this characteristic is only observed in $44 \%$ of its products, since in many of them the composition of the fruit concentrate, which contains large amounts of sugar, is not described.

$12 \%$ of products in the sample presented sodium within the first five positions in the list of ingredients, mainly the categories of cheeses (86\%) and prepared meats $(40 \%) .5 \%$ of the products contained sugar or other sweeteners and sodium within the first five positions of the list of ingredients, mainly in prepared meats (40\%) and sweetened breakfast cereals (16\%).

An evaluation was made of the price of 126 processed food products, of which 63 were functional and 63 conventional (Table 7). The categories of sweetened juices, seasonings, baked products, cheeses, cereal bars, prepared meats, sweetened breakfast cereals and cookies were evaluated in family presentation, while the category of sweetened and flavored yogurts was evaluated in its individual presentation. However, standardization of the price per product portion is recommended for future studies. T-Student test and ANOVA variation analysis were applied, showing a statistically significant difference $(\mathrm{P}=0.025)$ between $\mathrm{CPF}$ and PFF prices, with the PFF price being significantly higher $(\mathrm{P}=0.025)$. The average price of PFF was $\$ 2.34$ and $\$ 1.87$ for conventional foods, excluding sweetened and flavored yogurts in both. Sweetened breakfast cereals were the most expensive category and sweetened juices were the cheapest, for both PFF and conventional foods. The categories with the highest price difference were cereal bars (\$1.22) and cheeses $(\$ 0.90)$. 
Table 7. Price and price difference in U.S. dollars between PFF and conventional processed foods by food category.

\begin{tabular}{cccc}
\hline Food Category & $\begin{array}{c}\text { Functional } \\
\text { Average Price } \\
(\mathrm{n}=63)^{\mathrm{d}}\end{array}$ & $\begin{array}{c}\text { Conventional } \\
\text { Average Price } \\
(\mathrm{n}=63)\end{array}$ & $\begin{array}{c}\text { Price } \\
\text { Difference }\end{array}$ \\
\hline $\begin{array}{c}\text { Sweetened juices }(\mathrm{n}=15)^{\mathrm{b}} \\
\text { Seasonings }(\mathrm{n}=8)^{\mathrm{b}}\end{array}$ & $\$ 1.79$ & $\$ 1.39$ & $\$ 0.40$ \\
Baked products $(\mathrm{n}=17)^{\mathrm{b}}$ & $\$ 1.90$ & $\$ 1.62$ & $\$ 0.28$ \\
Cheeses $(\mathrm{n}=14)^{\mathrm{b}}$ & $\$ 1.88$ & $\$ 1.51$ & $\$ 0.36$ \\
Sweetened and flavored yogurts $(\mathrm{n}=16)^{\mathrm{c}}$ & $\$ 0.77$ & $\$ 1.62$ & $\$ 0.90$ \\
Cereal bars $(\mathrm{n}=9)^{\mathrm{b}}$ & $\$ 3.01$ & $\$ 0.69$ & $\$ 0.08$ \\
Prepared meat $(\mathrm{n}=9)^{\mathrm{b}}$ & $\$ 2.33$ & $\$ 1.79$ & $\$ 1.22$ \\
Sweetened breakfast cereals $(\mathrm{n}=16)^{\mathrm{b}}$ & $\$ 3.49$ & $\$ 2.18$ & $\$ 0.14$ \\
Cookies $(\mathrm{n}=22)^{\mathrm{b}}$ & $\$ 1.80$ & $\$ 3.28$ & $\$ 0.21$ \\
Total $(\mathrm{n}=126)$ & $\$ 2.34$ & $\$ 1.59$ & $\$ 0.21$ \\
\hline
\end{tabular}

${ }^{\text {a} E x c h a n g e ~ r a t e ~ o f ~ L . ~} 24.44$ (Central Bank of Honduras); ${ }^{\text {b} C a t e g o r i e s ~ e v a l u a t e d ~ i n ~ f a m i l y ~ p r e s e n t a t i o n ; ~}$ ${ }^{\mathrm{c}}$ Categories evaluated in individual presentation; ${ }^{\mathrm{d}}$ The sweetened and flavored yogurt category was not included when calculating the average and the lowest price because of the notable price difference on the individual and family size presentation.

\section{Discussion}

Honduras and the rest of the Central American countries have a high prevalence of chronic diseases and, at the same time, diseases due to deficiencies of essential nutrients, as a consequence of the consumption of highly caloric foods with limited nutrient content [17] [18] and other associated factors. During 2016 in the Latin America and the Caribbean region, a $6 \%$ increase was reported in the prevalence of undernourishment, and at the same time, overweight and obesity in $7 \%$ of children under the age of five. Particularly in Tegucigalpa, $54.2 \%$ of adults were overweight or obese [19] [20] [21]. As a potential strategy to contribute to the solution of this problem, functional foods have been introduced to the market in order to promote the prevention and control of diseases associated with poor eating habits [22].

Despite being a new concept for the population, the production of functional foods constitutes an emerging market with significant promise. The demand for functional products continues to increase worldwide and its supply grows as new research develops [23]. The understanding of their benefits and their capacity to contribute to public health has managed to influence food policies. In 2011, the General Law of Food Fortification was enacted in Honduras [24], as an instrument for the prevention of nutritional deficiencies.

However, the obsession with health makes consumers vulnerable to deceptive and even fraudulent advertising pressure of some products whose beneficial effects are speculative [25] [26], while they provide an excessive amount of critical nutrients. Given the lack of regulation, both for the composition and marketing 
of processed foods, more than 95\% of PFF evaluated, exceed one or more critical nutrients simultaneously, being marketed at a higher price for the alleged functional properties they confer. Even the reduced versions of the products exceeded the recommended quantities. The excessive consumption of these nutrients is widely associated with the increased risk of suffering from chronic diseases, such as cardiovascular disease, diabetes, hypertension, metabolic syndrome and some types of cancer [4].

Honduras does not have previous studies on the composition or categorization of PFF, however, studies have been conducted on the content of critical nutrients in conventional processed foods, obtaining similar results [19] [27] [28], where more than $70 \%$ of products exceeded the recommendation of added sugars and $37 \%$ exceeded the sodium limit; a figure that is even lower than that found in the present study.

\subsection{Functional Dairy Products}

The inclusion of functional ingredients in dairy-based processed products, such as yogurt and cheese, is increasingly common due to their nutritional, physical and chemical properties, constituting an effective mean for transporting vitamins and minerals, as well as other functional ingredients [26] [29] [30]. These include probiotics and prebiotics, whose health effects include decreased risk of intestinal cancer, relief of symptoms of irritable bowel syndrome, increased fecal excretion and reduced blood cholesterol [5] [26] [29] [30].

In recent years, yogurt has gained popularity establishing itself as a product of regular consumption in many countries of the world, however, the results show that most exceed the content of one or more critical nutrients, mainly sugar and saturated fats. Although the main characteristic observed in the cheeses a reduction in the fat content, all the products exceeded the recommendation of total fats and more than $70 \%$ exceeded three criteria of the nutrient profile, mainly total fats, saturated fats and sodium. Previous studies show that more than $90 \%$ of conventionally processed cheeses also exceeded the recommended content of both sodium and total fat [19].

\subsection{Functional Carbohydrate-Based Products}

Due to the increase in cases of overweight and obesity, new foods have been introduced, such as those made from whole grains including wheat, oats and rice, whose function is to help the consumer maintain an adequate weight, providing a satiating effect and increasing fiber consumption, which is usually below the recommended value [23] [26] [31]. Wheat has a high content of insoluble fiber, anthocyanins and vitamin $\mathrm{E}$, which contribute to the prevention of degenerative diseases, while rice contains anti-inflammatory properties, and oats, due to its content of beta-glucans, can lower blood cholesterol [32] [33] [34] [35].

The majority of baked products made from these cereals exceed the content of one or two critical nutrients, mainly sodium, as well as sweetened breakfast ce- 
reals, which also exceed the recommendation of sugar, compared to $90 \%$ of conventional sweetened breakfast cereals that also exceed the recommendation of added sugars, reported by other previous studies. Cereal bars and cookies showed an excessive content of all the critical nutrients; this is linked with the results of some studies that relate the consumption of these snacks with the increase in the epidemic of overweight, obesity and chronic diseases, mainly in children [36] [37].

\subsection{Functional Beverages}

Due to their abundant content of phenolic compounds, sweetened juices made from blueberries, grapes, strawberries, almonds, soybeans and rice reduce the risk of cardiovascular diseases [26] [38], however, the excess of sugar in these beverages has been widely reported in processed products where more than $95 \%$ exceeded this recommendation; a finding similar to that of the present study has found 93\% of sweetened juices high in sugar [19] [27] [28]. Many of these products claim to be sugar-free and contain one or more non-caloric sweeteners such as acesulfame $\mathrm{K}$ and sucralose in $22 \%$ of the juices in the sample. Some studies show an excess of sugar content in more than $90 \%$ of sweetened juices [19], coinciding with the results obtained in this study, in which more than $40 \%$ exceed the recommendation of the content of three critical nutrients, mainly sugar, sodium and total fats, particularly in almond, soy and rice beverages.

\subsection{Functional Fat Based Products}

Mayonnaises with added lemon and olive oil were identified; lemon provides abundant vitamin $\mathrm{C}$ protecting against cellular oxidation, while olive oil is related to prevention of cardiovascular diseases due to its content of oleic acid, vitamin E and phenolic compounds [26] [38]. As in previous studies, even in its reduced fat version, more than $80 \%$ of mayonnaise products exceeded the recommended content of total fats and saturated fats; these products were also identified as having triple the recommendation of sodium content [19].

\subsection{Functional Protein-Based Products}

Meat products are often considered unhealthy; however, the creation of functional versions represent an opportunity to change that perception [39]. The main characteristic observed in this category was the reduction of fat content which is considered an effective strategy to maintain an adequate weight and prevent obesity [31], however, as in packaged condiments, $80 \%$ of the products in this category, simultaneously exceeded the content of total fat, saturated fat and sodium with an average more than five times higher than the recommendation.

\section{Conclusions}

Processed functional foods marketed in Honduras have an excessive content of critical nutrients in most of the products analyzed, which would lessen the poss- 
ible benefits of a functional ingredient or the modification of the content of the product if any ingredient was reduced. The overall composition of a functional product, including the contribution of critical nutrients, will determine if it is truly convenient, justifying the additional cost they represent.

The present study demonstrates the need for rigorous and mandatory regulation in the production, advertising and sale of functional and conventional processed foods. A specific legal framework is required for this type of product to protect the consumer from the excessive content of critical nutrients and increased unjustified prices, as well as from publicity and health claims, guaranteeing that the products are strictly based on scientific evidence to ensure contribution to public health and not to a greater imbalance of diet and out-of-pocket expenses to the detriment of health and the economy.

\section{Limitations}

Because very few products provide information on their trans-fat content, this criterion from the PAHO nutrient profile model was not considered. In addition, due to time limitations, the price per serving was not calculated, but size standardization is recommended for future studies to calculate the sample's average price. The sample was taken from only one supermarket chain since it is one of the most affordable to the majority of the population, however, there are several supermarket chains in different cities of the country, which offer a greater variety of functional products but at higher prices.

\section{Acknowledgements}

The authors thank the Institute for Technology in Health Care (ITHC), which agreed to finance this study.

\section{Conflicts of Interest}

The authors declare no conflicts of interest regarding the publication of this paper.

\section{References}

[1] Galanakis, C. (2017) Nutraceuticals and Functional Food Components. Academic Press, London.

[2] Giacco, R., De Giulio, B., Vitale, M. and Cozzolino, R. (2013) Functional Foods: Can Food Technology Help in the Prevention and Treatment of Diabetes? Food and Nutrition Sciences, 4, 827-837. https://doi.org/10.4236/fns.2013.48108

[3] Sunkara, R. and Verghese, M. (2014) Functional Foods for Obesity Management. Food and Nutrition Sciences, 5, 1359-1369. https://doi.org/10.4236/fns.2014.514148

[4] Afshin, A., Sur, P., Fay, K., Cornaby, L., et al. (2019) Health Effects of Dietary Risks in 195 Countries, 1990-2017: A Systematic Analysis for the Global Burden of Disease Study 2017. The Lancet, 393, 1958-1972. https://doi.org/10.1016/S0140-6736(19)30041-8

[5] Illanes, A. (2015) Functional Foods and Biotechnology. Revista Colombiana de Bio- 
tecnología, 17, 5-8. https://doi.org/10.15446/rev.colomb.biote.v17n1.50997

[6] Santillán, E., Méndez, M. and Vélez, J. (2015) Functional Dairy Products and Their Benefits in Human Health. Selected Topics of Food Engineering, 8, 5-14.

[7] Jacobs Jr., D.R. (2014) What Comes First: The Food or the Nutrient? Executive Summary of a Symposium. The Journal of Nutrition, 144, 543S-546S.

https://doi.org/10.3945/jn.113.182840

[8] Watson, R. (2017) Nutrition and Functional Foods for Healthy Aging. Academic Press, London.

[9] Patel, P., Ellis, K., Sunkara, R., Shackelford, L., Ogutu, S., Walker, L., Herring, J. and Verghese, M. (2016) Development of a Functional Food Product Using Guavas. Food and Nutrition Sciences, 7, 927-937. https://doi.org/10.4236/fns.2016.710092

[10] Valenzuela, A., Valenzuela, R., Sanhueza, J. and Morales, G. (2014) Functional Foods, Nutraceuticals and Foshu: Are We Going towards a New Concept of Food? Revista Chilena de Nutricion, 41, 198-204. https://doi.org/10.4067/S0717-75182014000200011

[11] Coronado, M., Gutiérrez, R., Vega, S., Radilla, C., Vazquez, M. and Ramírez, M. (2015) Functional Foods, Old Age and Diabetes. Food and Nutrition Sciences, 6, 1507-1513. https://doi.org/10.4236/fns.2015.616155

[12] FAO (2013) Guidelines for the Use of Nutrition and Health Claims.

[13] WHO. Central American Technical Regulations.

[14] PAHO (2016) PAHO Nutrient Profile Model.

[15] Bejarano-Roncancio, J., Gamboa-Delgado, E., Aya-Baquero, E. and Parra, D. (2015) The Ultra-Processed Foods and Beverages That Enter Colombia through the Free Trade Agreement Will Influence the Weight of Colombians? Revista Chilena de Nutricion, 42, 409-413. https://doi.org/10.4067/S0717-75182015000400014

[16] Foreign Trade Information System SICE (2018) Information about Honduras.

[17] Hernandez, A., Singh, P., Andino, C., Carlos, U., Daneri, A. and Flores, Z. (2015) Characterization of Habits Related to Chronic Diseases in the University Population of Honduras. Revista Cubana de Salud Pública, 41, 324-334.

[18] Carbajal-Flores, F. (2016) Evaluation of Academic Performance with the Implementation of School Meals: Honduras Case 2016-2017. Iberoamerican Journal of Bioeconomy and Climate Change, 2, 110-120. https://doi.org/10.5377/ribcc.v2i1.5687

[19] Hernández, A., Di Iorio, A. and Tejada, O. (2018) Content of Sugar, Fat and Sodium in Foods Marketed in Honduras, According to the Nutritional Labeling: Test for the Regulation of Processed and Ultra-Processed Foods. Revista Española de Nutrición Humana y Dietética, 22, 108-116. https://doi.org/10.14306/renhyd.22.2.413

[20] FAO (2018) The State of Food Security and Nutrition in the World.

[21] FAO (2017) The Panorama of Food and Nutrition Security in Latin America and the Caribbean.

[22] Serpa, A., Vélez, L., Barajas, J., Castro, C. and Zuluaga, R. (2016) Iron Compounds for Food Fortification: The Development of an Essential Nutritional Strategy for Developing Countries-A Review. Acta Agronómica, 65, 340-353. https://doi.org/10.15446/acag.v65n4.50327

[23] Fuentes-Berrio, L., Acevedo-Correa, D. and Gelvez-Ordoñez, V. (2015) Functional Foods: Impact and Challenges for the Development and Well-Being of the Colombian Society. Biotechnology in the Agricultural and Agroindustrial Sector, 13, 140-149. https://doi.org/10.18684/BSAA(13)140-149 
[24] La Gaceta (2011) General Law of Food Fortification. Power of Attorney.

[25] María, T.-L.E. and Josep, B.-M. (2015) Functional Foods: Need or Luxury? Revista Española de Nutrición Humana y Dietética, 19, 1-3. https://doi.org/10.14306/renhyd.19.1.153

[26] González, L., Perea, J. and Ortega, R. (2015) Functional Foods in the Context of the Mediterranean Diet. Mediterranean Economic, 27, 139-160.

[27] Hernández, A., Di Iorio, A., Lansdale, J. and Salazar, M. (2018) Characterization of the Types of Sweeteners Consumed in Honduras. Nutrients, 10, 338. https://doi.org/10.3390/nu10030338

[28] Hernández, A., Mejía, S., Di Iorio, A. and Mérida, C. (2019) How Do Commercial Children's Foods Influence Their Growth and Development? A Map of Commercially Available Children's Foods in Honduras. Food and Nutrition Science, 10, 174-187. https://doi.org/10.4236/fns.2019.102013

[29] Santillán, E., Méndez, M. and Vélez, J. (2015) Functional, Fortified Dairy Products and Their Benefits in Human Health. Selected Topics of Food Engineering, 8, 5-14.

[30] Hernández, M. and Vélez, J. (2014) Whey and Its Application in the Preparation of Functional Foods. Selected Topics of Food Engineering, 8, 13-22.

[31] Martínez-Álvarez, J.R. (2016) Obesity and Functional Foods: Are the New Ingredients and Products Effective? Journal of Medicine of the University of Navarra, 4, 31.

[32] Chaquilla-Quilca, G., Balandrán-Quintana, R., Mendoza, A. and Mercado-Ruiz, J. (2018) Properties and Possible Applications of Wheat Bran Proteins. Ciencia UAT, 12, 137-147. https://doi.org/10.29059/cienciauat.v12i2.883

[33] Mellado, M. and Haros, M. (2016) Evaluation of the Technological, Nutritional and Sensory Quality of Bakery Products by Replacing Wheat Flour with Whole Meal Rice Flour. Brazilian Journal of Food Technology, 19, 1-9. https://doi.org/10.1590/1981-6723.0216

[34] Pérez, S. and Granito, M. (2015) High-Protein Chocolate Drink Based on Fermented Cajanus cajan and Oats. Anales Venezolanos de Nutrición, 28, 11-20.

[35] Quezada, L. et al. (2017) $\beta$-Glucans in Native Starch from Breadfruit and Their Potential Use in Functional Foods. Ciencia UNEMI, 10, 82-87. https://doi.org/10.29076/issn.2528-7737vol10iss24.2017pp82-87p

[36] Herrán, O.F., Del Castillo, S. and Fonseca, Z.Y. (2015) Snack Consumption and Excess Weight in Colombian Children. Revista Chilena de Nutricion, 42, 224-234. https://doi.org/10.4067/S0717-75182015000300001

[37] Mamani, R. and Mejía, T. (2018) Cellular Oxidative Stress and Diabetes for Snack Type Refined Foods? Hospital Journal Hipólito Unanue, 11, 15-21.

[38] LLanes, J. (2017) Lipid-Lowering Foods That Improve Cardiovascular Health. Cuban Journal of Cardiology and Cardiovascular Surgery, 23, 549-582.

[39] Grasso, S., Brunton, N.P., Lyng, J.G., Lalor, F. and Monahan, F.J. (2014) Healthy Processed Meat Products-Regulatory, Reformulation and Consumer Challenges. Trends in Food Science \& Technology, 39, 4-17. https://doi.org/10.1016/j.tifs.2014.06.006 